\title{
The Challenging Behaviors Faced by the Preschool Teachers in Their Classrooms, and the Strategies and Discipline Approaches Used against These Behaviors: The Sample of United States
}

\begin{tabular}{|c|c|}
\hline Tokat Gaziosmanpa & $\begin{array}{l}\text { P1nar Aksoy* } \\
\text { versity, Faculty of Education, Department of Preschool Education, } \\
\text { at, Turkey, ORCID: 0000-0001-6107-3877. }\end{array}$ \\
\hline Article history & This research aims to investigate the most frequent challenging behaviors \\
\hline $\begin{array}{l}\text { Received: } \\
27.03 .2020\end{array}$ & $\begin{array}{l}\text { faced by preschool teachers in their classrooms and the strategies and } \\
\text { discipline approaches they adopt against these challenging behaviors. }\end{array}$ \\
\hline $\begin{array}{l}\text { Received in revised form: } \\
07.05 .2020\end{array}$ & $\begin{array}{l}\text { This research is conducted within case study design, which is a } \\
\text { qualitative research method. The study group consists of } 10 \text { different } \\
\text { preschool teachers teaching for children aged four-five in a city in the }\end{array}$ \\
\hline $\begin{array}{l}\text { Accepted: } \\
28.05 .2020\end{array}$ & $\begin{array}{l}\text { mid-south region of the United States. The research data was collected } \\
\text { through one-to-one interviews performed by the researcher with the }\end{array}$ \\
\hline Key words: & \\
\hline $\begin{array}{l}\text { Preschool; } \\
\text { teacher; } \\
\text { challenging behaviors; } \\
\text { strategy; } \\
\text { discipline approach; }\end{array}$ & $\begin{array}{l}\text { result of the interviews with the teachers. In the study, the challenging } \\
\text { behaviors faced by the preschool teachers were asserted as the behaviors } \\
\text { occurring under the themes of "accommodation problems" in the first } \\
\text { place, followed by "self-control inadequacies" and then "absence of } \\
\text { prosocial behaviors", and "deficiencies in assertiveness skills". The } \\
\text { result of this study showed that preschool teachers mainly adopted } \\
\text { multiple appropriate strategies which contribute to creating a warm } \\
\text { classroom environment in their classrooms. It was stated that the } \\
\text { discipline approach based on behavior change was mostly used as well } \\
\text { as the instructional and effective communicational approach was } \\
\text { partially used, while the assertive discipline approach was rarely used. It } \\
\text { is recommended that the strategies and discipline approaches of teachers } \\
\text { for dealing with challenging behaviors should be positively improved } \\
\text { through supporting the knowledge, skills, and experiences of preschool } \\
\text { teachers in the dimension of classroom management. }\end{array}$ \\
\hline
\end{tabular}

\section{Introduction}

A child is in need of inquiring and searching his/her environment, moving, exploring, learning new things, and playing games during preschool period that covers the first six years of the life. The process of satisfying this need has an impact on gaining the knowledge, skills, attitudes, and habits, which form the basis of his/her life. Preschool educational institutions are turned to at the point of delivery of the education professionally and in an organized environment like schools, during this period that plays a very huge role in child's future life (seen in Couchenour \& Chrisman, 2016; Cutter Mackenzie, Edwards, Moore, \& Boyd, 2016). Activities adopted by the teachers by means of the practices s/he performs in a planned and

\footnotetext{
*Correspondency: aksoypnr@gmail.com
} 
organized manner within the framework of education and training at the educational institutions support the function of the educational institution. The quality of this process is affected by conditions such as the occupational competency, practical experience, and classroom management skill of teacher. Challenging behaviors arise as a condition that not only obstructs the classroom management by preschool teachers, but also affects the children's development and learning negatively, decreasing the efficiency of the process of education (Aygün, Yildizbas \& Aygün, 2014; Bredekamp, 2016; Buckwalter, Reed \& Sunshine, 2020; DiGennaro, Martens, \& Kleinmann, 2007; Gülay Ogelman \& Ersan, 2014; Tincani, 2011).

The relevant studies (e.g., Bulotsky Shearer, Fernandez, Dominguez, \& Rouse, 2011; Hayes, 2007; Keane \& Calkins, 2004; Lavigne et. al., 1998; Shaw et. al., 1998; Yagan Güder, Alabay, \& Güner, 2018) in the literature point out many negative aspects of challenging behaviors in preschool children. The challenging behaviors observed in the preschool children weaken communications with peers, decrease the quality of the educational process, and reduce the performances and job satisfaction of teachers. It is suggested that the challenging behaviors exhibited during the preschool period have a negative impact on children's attitudes towards learning in their future ages, academic achievements, skills of attention and motivation (Bulotsky Shearer et. al., 2011). An empirical research detected that the presentation of problem behavior varies in the preschool period and that heterotypic continuity of the problems is very common among preschool children. In this research, it was emphasized that children with internalizing and externalizing problems were most likely to show persisting problems (Basten et. al., 2016). It was stated that part of the preschool children exhibits challenging behaviors at home or at school in some way (Powell, Fixsen, \& Dunlap, 2003). Based on these, it can be offered that eliminating challenging behaviors starting from the preschool period plays an important role in the children's life.

It is accepted that it is required to address the challenging behaviors starting from the preschool period, and the need for making a realistic evaluation on the challenging behaviors comes to existence, as well. In fact, it is possible that preschool children exhibit incorrect or limited behaviors due to the inadequacies in their balance coordination, limitations in their cognitive capacities, and deficiencies in their social skills. Addressing these behaviors directly as challenging behaviors causes an unrealistic evaluation on the children. Challenging behaviors may originate from the uncertainties in the rules, inadequacies in the educational environment, and disruptions in the classroom management. Hence, unfavorable behaviors, which continue their existence intensively even when the abovementioned conditions are improved and the impacts of the unfavorable stimulus at the background are minimized, might be an indicator of an inadequacy (Aksoy, 2018). There are different classifications for the challenging behaviors, and the behaviors having certain characteristics are named as challenging behaviors in general. Challenging behaviors may be described as follows: (a) although a child has a sufficient capacity mentally, emotionally, and physically, s/he exhibits improper behaviors, (b) repeats unfavorable behaviors frequently, (c) exhibits improper behaviors in a manner to obstruct the educational process, (d) inhibits his/her own and his/her peers' learning process at the same time, (e) creates a physically/psychologically menacing situation for himself/herself and for his/her environment, (f) damages the environment financially (Honig, 1997; Levin, \& Nolan, 2007; Morris, Shah, \& Morris, 2002). These conditions are described as behavioral disorders by Merrell (2003). According to Merrell's classification, behavioral disorders are classified into two categories as externalizing (externalized) behaviors and internalizing (internalized) behaviors. Externalizing behavior problems represent extrinsic abnormal behaviors such as aggressiveness and hyperactivity, while internalizing behavior problems explain the abnormal 
behaviors such as introversion, somatic problems, and anxiety exposed to the individual by himself/herself.

The solutions for the abovementioned challenging behaviors are also possible by improving the strategies of the preschool teachers for competing with the unfavorable situations and if the preschool teachers adopt the steps in the body of effective discipline approaches. Otherwise, it is inevitable that preschool education services delivered in a somehow unorganized manner through persons, institutions, or environment trigger challenging behaviors of the children. Accordingly, the process of preventing challenging behaviors is not independent from the process of practicing effective strategies and positive discipline approaches (Aygün, Yildizbas \& Aygün, 2014; Ellis, 2018; Johansen, Little \& Akin Little, 2011; McCabe \& Frede, 2007; Parsonson, 2012; Reinke, Lewis Palmer \& Merrell, 2008).

In fact, different discipline approaches focus on different situations, and it is emphasized that certain practices should be performed by means of different strategies. In general, these are classified in the literature as behavior modification based discipline approach, control approach (reality therapy), social discipline (rational choices) approach, assertive discipline approach, instructional approach, and effective communication approach (e.g.; Canter \& Canter, 1992; Edwards, 1993; Glasser, 1992; Jones \& Jones, 2007; Wolfgang, 1995). The behavior modification based discipline approach emphasizes that behaviors emerge through the bond established between the stimulus and behavior, based on the principles of the behaviorist theory. The control behavior asserts that any environment oriented at children should be organized to meet the needs of the children, that a behavior is determined through the needs such as vital needs, the needs of belonging, power, entertainment, and freedom; and unsatisfied needs are the causes for the challenging behaviors to emerge. The social discipline approach also suggests that the needs such as being accepted by people and belonging to a group lie behind the behaviors. Meanwhile, the assertive discipline approach bases on reminding the rules calmly and consistently, and on the fact that teachers remind the students of the borders of the rules and explain what the results would be if the students do not follow them. The instructional approach emphasizes that the challenging behaviors will be reduced by preventing the children who keep being active from getting bored, mentioning that preventive solutions should be chosen against challenging behaviors. Additionally, the effective communication approach based on the opinions of the theorists sets forth that challenging behaviors may not be eliminated by means of methods such as intimidating and punishment. The effective communication approach counting upon the importance of developing good relationships between the teacher and the student, objects to the traditional teacher models. Accordingly, the focal points of the discipline approaches differentiate from each other and the steps suggested by them to follow against challenging behaviors vary.

Basing on the fact that each child may have his/her own unique characteristics and different learning styles, the importance placed on the functional strategies and effective approaches that can be used against challenging behaviors exhibited by the children increases. Considering that once it is identified what the challenging behaviors are, it is possible to start the efforts to prevent them; identification of the challenging behaviors is a primary step to take at this point. It is beyond any doubt that it is possible to start the efforts to eliminate or reduce the challenging behaviors at the stage after the identification of the challenging behaviors. At this stage, the strategies adopted against the challenging behaviors and the discipline approaches containing these strategies are highlighted. In the recent years, descriptive studies on challenging behaviors has increased (e.g., Aygün, Yildizbas \& Aygün, 2014; Bulotsky Shearer et. al., 2011; Kremer, Flower, Huang \& Vaughn, 2017; Miller, Smith Bonahue \& Kemple, 2017; Topcu Bilir \& Sop, 
2016), while the studies addressing the strategies implemented against challenging behaviors have been in the minority. While these minority studies include the analyses of the strategies used for challenging behaviors (Buyuktaskapu Soydan, Alakoc Pirpir, Ozturk Samur, \& Angin, 2018; Dal \& Akan, 2018; Jolivette \& Steed, 2010; Medikoglu \& Dalaman, 2018; Oztürk \& Gangal, 2016 etc.); as there is no study found to analyze the strategies used in the preschool period from a holistic view with the discipline approaches. It is thought that the results obtained from a study to be conducted on this point would contribute to educators as well as researchers on the useful practices to be carried out and the effective approaches to be exhibited in the field of preschool education. It is anticipated that the results of the study will be a guide for presenting different strategies to adopt against the challenging behaviors in the preschool period, identifying the steps around the effective discipline approaches, and recognizing the alternative practices that might be used for competing with the challenging behaviors, as well.

\section{The Aim of the Study}

This research aims to investigate the most frequent challenging behaviors faced by preschool teachers in their classrooms and the strategies and discipline approaches they adopt against these challenging behaviors. In this line, this research seeks answers to the following questions.

1) What are the most frequent challenging behaviors faced by the preschool teachers in their classrooms?

2) What are the strategies and discipline approaches used by the preschool teachers against the most frequent challenging behaviors in their classrooms?

\section{Method}

\section{Research Design}

This research is conducted within the case study design, which is a qualitative research method. A qualitative process is followed to reveal perceptions and events in their natural environment in a realistic and holistic manner, using the data collection methods such as observation, interview, and document analysis in the qualitative research. Case study is an approach used very commonly in the qualitative research. One or more cases are researched extensively in qualitative case study (Creswell, 2009; Yildirim \& Simsek, 2008; Yin, 2009). The condition handled in the study is comprised of the challenging behaviors faced by the preschool children in their classrooms and the strategies and discipline approaches used by the teachers of these classrooms. The situation tackled in the study was examined in the institutions of similar structure in a city in the mid-south region of the United States.

\section{Study Group}

While choosing the study group, the teachers who were volunteer/could allocate time to participate in the study among the teachers who worked at different preschool institutions that can be accessed by the researcher in a city in the mid-south region of the United States were reached (through a visit of the researcher to the teachers' institution) with an easy-to-reach case sampling as the first phase. The purposive sampling method, was adopted to determine the preschool teachers who were working at 23 different preschool education institutions reached in this line and who had children exhibiting challenging behaviors (such as emotional and/or behavioral problems/difficulties) in their classrooms. In this scope, 10 preschool teachers 
among the ones who had children exhibiting challenging behaviors and who were volunteer to participate in the study were enrolled to the study. Among the initial visits, the information related to the context of challenging behaviors faced by preschool teachers was gathered and the final cases was drawn by having the availability for participation criteria. This process is based to the behavioral characteristics described by the teachers in the study group. According to this, the study group consists of 10 different preschool education institutions for four and five-age children in the state of mid-south region of the United States during the spring semester of 2017-2018 academic year, and 10 preschool teachers working at these preschool education institutions. Head teachers from each class (the most senior teacher in the classroom) were included into the scope of the study. Each of the preschool teachers in the study group worked at a different institution and all of them were female. The great majority of the teachers in the study group $(n=6)$ had 15 years and more professional experience while some of the teachers $(n=3)$ had the experience between 5-10 years, and one of them had 3 years of professional experience. The ages of these teachers varied from 27 to 46 years old and the majority $(n=5)$ were between $36-40$ years old.

\section{Data Collection Process}

Research data consists of the data obtained through one-to-one interviews performed by the researcher with the teachers. The research data was collected using the interview method. The researcher carried out face-to-face interviews with the teachers on the days and at the times when the teachers were available within the body of the institution and within the scope of the permission obtained for the research. Each interview with the teachers took 45 minutes on average. The data was collected between March 24 and May 2 in 2018. The researcher asked the teachers questions within the scope of the semi-structured interviews in order to collect data. Patton (2002) suggests that semi-structured interviews are carried out by preparing predefined questions for the purpose of obtaining same types of information from the participants, focusing on similar matters. In this scope, the teachers were asked the following two open-end questions: (1) "What is the most frequent challenging behavior exhibited by the children in your classroom?" and (2) "What are the strategies you adopt against the most frequent challenging behaviors exhibited by the children in your classroom?". In generating interview questions for collecting data, methods of studies that can serve the purpose of the study were reviewed (such as Aygün, Yildizbas \& Aygün, 2014; Bulotsky Shearer et al., 2011; Buyuktaskapu et. al, 2018; Jolivette \& Steed, 2010; Kremer et. al., 2017; Miller, Smith Bonahue \& Kemple, 2017; Oztürk \& Gangal, 2016; Topcu Bilir \& Sop, 2016). Collecting data through interview in the study contributes to revealing challenging behaviors and teacher behaviors that cannot be observed at a certain time. It was taken consideration to ensure that the questions that form the basis of the interviews with teachers are the type that can reveal the main data for the aim of the study. There was no time limit for the interviews with the teachers, and teachers were encouraged to focus on the answers to the two questions. The researcher recorded the answers by the teachers by writing them down and convert the notes to written format transferring them to the computer environment identically. The study data obtained in this line is limited to the data obtained as a result of the interviews with the teachers in the study group.

\section{Data Evaluation}

Qualitative data analysis methods were used to evaluate the data in this study, which was conducted in order to study the most frequent challenging behaviors faced by the preschool teachers in their classrooms and the strategies adopted by them to compete with these challenging behaviors, and their discipline approaches. Content analysis was used to analyze 
the data obtained as a result of the interviews with the teachers. Content analysis is a process of analysis aiming to reach the concepts/relations that can explain the collected data and is used for discovering the concepts and themes, which cannot be recognized by means of a descriptive approach. In this respect, content analysis requires deeply analyzing the collected data and ensures revealing the themes/dimensions that are related to the subject of the study. The basis of content analysis is to combine similar data within the framework of certain concepts and themes and to organize and interpret such data clearly. In this framework, the collected data must firstly be conceptualized, and then organized logically according to the emerging concepts, and the themes that explain the data accordingly must be determined (Creswell, 2012; Denzin \& Lincoln, 2011; Yildirim \& Simsek, 2008; Yin, 2009). The analysis processes of content analysis consisting of four phases were used to process the qualitative research data obtained from the interviews with the preschool teachers in this study. These processes are provided below.

1. Coding the data: The researcher analyzed the information obtained from the interviews and tried to divide it into significant chapters, and highlighted what each of the chapters meant conceptually at the phase of coding of data, which is the first phase of the content analysis. At this phase, the texts obtained from the interviews with the teachers were read several times and the challenging behaviors and the strategies specified in the texts were identified. The challenging behaviors and the strategies were addressed as the concepts used in coding at this phase. While forming the challenging behaviors that represent the concepts in the coding, the most common expression in the literature was based on as a result of the researcher's literature review. In this framework, the codes were created according to the concepts found out from the data directly, and coding was performed according to the challenging behaviors implied from the statements obtained from the interviews with the teachers. Thus, the lists of codes were created with an inductive approach. These include fighting (T1), telling their wishes by crying (T2), speaking by interrupting others (T3), remaining passive/not asking for permission to speak (T4), speaking too loudly/shouting out/hesitating to participate in plays (T5), talking among themselves/not focusing on their studies (T6, T7), participating in a group harming others/not sharing/not waiting their turns, fighting/pushing around each other (T8), having problems in sharing (T9), not following classroom rules/avoiding following classroom instructions (T10). In addition to this, a literature review was performed in order to determine the strategies and the discipline approaches used against the challenging behaviors. The researcher determined the strategies used against the behaviors that were coded according to the strategy, which was represented by these behaviors and was mentioned in the statements of the teachers during the interviews, and what the discipline approaches that defend this strategy are, basing on the relevant literature review. The strategies in this scope were reviewed within the scope of the discipline approaches of behavior modification based discipline approach, control approach, social discipline approach, assertive discipline approach, instructional approach, and effective communication approach among the commonly mentioned approaches in the literature. In this line, the codes that were created were used as a conceptual basis for the study data.

2. Finding the themes: It was ensured that the themes, which could explain the data on the challenging behaviors at a general level and classify the challenging behaviors under certain categories basing on the created codes, were found at the second phase of the content analysis. While finding the themes, the codes that were determined at the first phase were combined and the differences and similarities between these codes were assessed at first. Based on this, it was tried to determine themes that combine the determined challenging behaviors. In this line, the scope and framework of the challenging behaviors asserted during the interviews with the teachers were reviewed. During the review, it was detected that the challenging behaviors which 
were coded at the abovementioned first phase correspond to the negative forms of the items representing the dimensions in the Social Skills Assessment Scale developed by Aksoy (2014) in some way. In this line, the classification suggested by Aksoy (2014), which is already available in the literature, was utilized to create the themes of the existing challenging behaviors. According to Aksoy (2014), the social skills of the preschool children consist of the behaviors at the dimensions of communication, accommodation, self-control, prosocial behaviors, and assertiveness. Among the behaviors included in the codes determined in this study; speaking by interrupting others (T3), talking among themselves/not focusing on their studies (T6, T7), not waiting their turns (T8), not following classroom rules/avoiding following classroom instructions (T10) represent the negative forms of the social skills in the "accommodation" dimension, while fighting (T1, T8), speaking too loudly/shouting out (T5), pushing around each other/participating in a group harming others (T8), having problems in sharing (T9) represent the negative forms of the social skills in the "prosocial" dimension, and remaining passive/not asking for permission to speak/hesitating to participate in plays (T4) represent the negative forms of the social skills in the "assertiveness" dimension. In the study, as the teachers were requested to express the situations they face in regards to the challenging behaviors, the behaviors that were stated corresponded to the behaviors with negative social content. Based on these steps, it was preferred to code the study themes as "accommodation problems", "self-control inadequacies", "absence of prosocial behaviors", and "deficiencies in assertiveness skill", representing the challenging behaviors for the purpose of reflecting the data implicitly and organizing the data set effectively. Then, the themes that were formed by the data set were submitted to two experts who worked as instructors in the field of Preschool Education and to a lecturer who was expert in the field of classroom management at the Department of Educational Sciences, for their opinions. In this line; the codes associated with the challenging strategies and the themes representing them, as well as the strategies used against these behaviors and the discipline approaches containing these strategies were reviewed. The consensus at this stage was examined by means of the Miles and Huberman (1994) formula (Reliability $=$ Consensus/Consensus + Dissensus $x$ 100). As a result of the evaluation, the values of consensus and dissensus were calculated and it was found that different evaluations were made for the two discipline approaches with the field expert of Preschool Education and for the three discipline approaches with the field expert of Educational Sciences Department. Accordingly, it was detected that the rate of consensus in the study was between $87.87 \%$ and $90.90 \%$. In the meantime, it is specified by Miles and Huberman (1994) that if a rate around 90\% achieved in qualitative researches, it is highly reliable for the consensus of researcher/experts. The phase of coding data and creating themes was completed following the steps to ensure internal and external consistency.

3. Organizing and Describing the Data basing on the Codes and Themes: At this phase, the data obtained in the study was organized basing on the codes and themes that were found. Attention was paid to explain and present the data in an understandable manner. Hence, it was preferred to use clear and comprehensible concepts at the phases of coding the challenging behaviors, classifying the coded behaviors under the themes, and determining the strategies and discipline approaches used against the challenging behaviors. The data that was classified under the same code or theme but mentioned in different statements were presented collectively basing on their relations with each other, when needed, and the obtained information was set forth in an organized manner.

4. Interpreting the findings: The last phase of the content analysis included definition of the obtained findings and interpretation of the results by the researcher. At this phase; firstly, the challenging behaviors faced by the preschool teachers in their classrooms and the situations 
representing them were emphasized; secondly, the strategies adopted against the challenging behaviors and the discipline approaches containing these strategies were explained. In this section, the researcher tries to explain the findings, to suggest results basing on the findings, to make a discussion based on the literature regarding the results, and to present suggestions in the framework of cause-effect relations. The information and findings reached in this scope are revealed trustingly and explained in the relevant sections in accordance with the original.

\section{Findings}

In this section, the findings related to the most frequent challenging behaviors faced by the preschool teachers in their classrooms and the strategies they use to compete with these behaviors, and the discipline approaches are provided. In this framework, the obtained data is presented in the tables. In this line, the quotations obtained as a result of the interviews with the teachers are mentioned directly, and it is aimed to support the study findings by means of realistic data. The real names of the teachers in the study group are not mentioned, and code names are used for each teacher giving them a sequence number as T1, T2, T3, T4, T5, T6, T7, T8, T9, and T10 instead of their real names. Based on this point, the obtained findings are provided upon being organized for the purpose of the study.

Table 1. The challenging behaviors faced by the preschool teachers in their classrooms

\begin{tabular}{lc} 
Challenging Behaviors Faced in Classroom & Teachers \\
\hline Accommodation Problems & $\mathrm{T} 3$ \\
\hline Speaking by interrupting others & $\mathrm{T} 6, \mathrm{~T} 7$ \\
Talking among themselves/Not focusing on their studies & $\mathrm{T} 8$, \\
Not waiting their turns & $\mathrm{T} 10$ \\
Not following classroom rules & $\mathrm{T} 10$ \\
Avoiding following classroom instructions & $\mathrm{T} 1, \mathrm{~T} 8$ \\
\hline Self-Control Inadequacies & $\mathrm{T} 5$ \\
\hline Fighting & $\mathrm{T} 8$ \\
Speaking too loudly/Shouting out & $\mathrm{T} 8$ \\
\hline Pushing around each other & $\mathrm{T} 2$ \\
Participating in a group harming others & $\mathrm{T} 8, \mathrm{~T} 9$ \\
\hline Absence of Prosocial Behaviors & $\mathrm{T} 4$ \\
\hline Telling their wishes by crying & $\mathrm{T} 4$ \\
Not being eager to share & $\mathrm{T} 4$ \\
\hline Inadequacies in Assertiveness Skill & \\
\hline Remaining passive & \\
\hline Never asking for permission to speak & \\
\hline
\end{tabular}

As provided in the Table 1, when the quotations obtained from the interviews with the preschool teachers are analyzed, it is seen that the challenging behaviors asserted by the teachers to be faced in their classrooms differ from each other.

Table 2. The strategies and discipline approaches adopted by the preschool teachers against the "accommodation problems" they face in their classrooms

\begin{tabular}{|c|c|c|}
\hline \multicolumn{3}{|c|}{ Challenging Behaviors Faced in the Classroom } \\
\hline Accommodation Problems & Strategies & Discipline Approaches \\
\hline \multirow[t]{2}{*}{ Speaking by interrupting (T3) } & $\begin{array}{l}\text { Declaring to the child that } \\
\text { teacher is aware of his/her } \\
\text { behavior }\end{array}$ & Instructional approach \\
\hline & $\begin{array}{l}\text { Giving hints through body } \\
\text { language/Giving hints through }\end{array}$ & $\begin{array}{l}\text { Behavior modification based on } \\
\text { discipline approach }\end{array}$ \\
\hline
\end{tabular}




\begin{tabular}{|c|c|c|}
\hline & vocal signs & \\
\hline \multirow{2}{*}{$\begin{array}{l}\text { Talking / } \\
\text { Not focusing their attention on } \\
\text { their studies (T6) }\end{array}$} & $\begin{array}{l}\text { Demonstrating the awareness of } \\
\text { the teacher through behaviors }\end{array}$ & Instructional approach \\
\hline & $\begin{array}{l}\text { Encouraging the child to } \\
\text { evaluate and change the } \\
\text { challenging behavior }\end{array}$ & $\begin{array}{l}\text { Control approach } \\
\text { (Reality therapy) }\end{array}$ \\
\hline $\begin{array}{l}\text { Talking too much among each } \\
\text { other/Being less busy with their } \\
\text { studies (T7) }\end{array}$ & $\begin{array}{l}\text { Determining logical sanctions } \\
\text { (Inviting family to the school) }\end{array}$ & Assertive discipline approach \\
\hline \multirow[b]{2}{*}{ Not waiting their turns (T8) } & $\begin{array}{l}\text { Use of positive } \\
\text { (symbolic) reinforcement }\end{array}$ & $\begin{array}{l}\text { Behavior modification based } \\
\text { discipline approach }\end{array}$ \\
\hline & $\begin{array}{l}\text { Use of positive (social content) } \\
\text { reinforcement }\end{array}$ & $\begin{array}{l}\text { Behavior modification based } \\
\text { discipline approach }\end{array}$ \\
\hline \multirow{3}{*}{$\begin{array}{l}\text { Not following classroom rules/ } \\
\text { Avoiding following the } \\
\text { instructions (T10) }\end{array}$} & $\begin{array}{l}\text { Use of negative } \\
\text { (symbolic) reinforcement }\end{array}$ & $\begin{array}{l}\text { Behavior modification based } \\
\text { discipline approach }\end{array}$ \\
\hline & $\begin{array}{l}\text { Use of positive } \\
\text { (symbolic) reinforcement }\end{array}$ & $\begin{array}{l}\text { Behavior modification based } \\
\text { discipline approach }\end{array}$ \\
\hline & $\begin{array}{l}\text { Use of positive (social content) } \\
\text { reinforcement }\end{array}$ & $\begin{array}{l}\text { Behavior modification based } \\
\text { discipline approach }\end{array}$ \\
\hline
\end{tabular}

Analyzing Table 2, it is observed that the teachers who highlighted the challenging behaviors within the scope of the accommodation problems (T3, T6, T7, T8, T10) adopt strategies like using reinforcements (positive/negative) significantly and mainly benefit from behavior modification based discipline approaches (T3, T8, T10). Within this scope, the strategies of a preschool teacher (T3) used in case of any children "speaking by interrupting others" to declare the children that the teacher is aware of their behaviors through expressions such as "you should wait", "it is your friend's turn", "you should let him/her speak" are the skills emphasized by the instructional approach. It can also be said that the teacher use the behavior modification based discipline approach that contains the strategies in which the teacher reminds the child that $\mathrm{s} / \mathrm{he}$ should stop his/her behavior by means of giving a hint by body language with a "Stop!" sign and giving a hint by vocal sign telling him/her "Now you are waiting". The quotations picked from the interviews with the T3 are provided below.

T3: Some of them exhibit the behavior of speaking by interrupting others. In such
cases, I remind them of the proper behavior through sentences such as "you should
wait now", "it is your friend's turn", and "you should let your friend speak." And
sometimes by making a "Stop!" gesture, I tell them that in fact they have to wait for
speaking. I think this works so well. When I make a "Stop!" gesture pointing
him/her, ensuring s/he sees it, and warn him/her verbally saying "Now you are
waiting", s/he can get aware of his/her behavior. And as the children have difficulty
in controlling themselves instinctively, they tend to start speaking by interrupting
others. It can be useful if we show them the correct behavior instead of this
behavior.

It is observed in Table 2 that two different preschool teachers (T6, T7) in the study group stated that there is the challenging behavior of "talking among each other and not being busy with their studies adequately" within the scope of "accommodation problems" in their classrooms. Considering the strategies and the discipline approaches used by these teachers, it can be suggested that one of the teachers (T6) practices the awareness skill, one of the skills of instructional approach asserting that less challenging behaviors will be exhibited thanks to the teacher indicating with his/her behaviors that $\mathrm{s} / \mathrm{he}$ is aware of to whom the child speaks mostly (ensuring that these children do not have seats side by side). Nevertheless, it was detected that the teacher encourages the children to evaluate-change the challenging behavior by means of 
the expressions such as "I think you have something to do, what about going on it?", within the scope of the control approach that emphasizes the problem solving phases to be implemented towards a child who exhibits the challenging behavior. It was detected that another teacher (T7) uses the process of inviting the family to the school, one of the sanctions of the assertive discipline approach. The following expressions are the examples of these cases.

T6: In our classroom, challenging behaviors do not occur much in general, but the children's behavior of not focusing on their studies due to talking among each other is widely observed. The children in my classroom this year are very talkative in general; some of them try to talk to each other at every opportunity immediately. If this happens to prevent them from focusing on their study, then I get aware which child talks to whom at the most, and I try not to let them be side by side when I queue them or when I group them for activities. It is a good behavior that they share something and communicate with their friends, but if they cannot complete their activities or disturb the others in the classroom due to this, I let them know that in fact I am aware of their behavior saying "I think you have something to do, what about going on it?". Then, they refocus on their studies, but sometimes they may talk among each other again.

T7: Behaviors such as harming each other or fighting among each other never occur in my classroom, I am very lucky. Just some of the children talk to each other too much and are less busy with their studies, which is a non-social behavior. In some cases, I invite their parents to the school due to these problems, and I discuss the situation with them. But I see that some of the talkative children's mothers visit the school and speak to me for hours. Even sometimes I can find very little chance to speak while they are speaking. Then I think that it means the child experiences it at home and keeps on trying to do the same at the school. I share the situation of the child with them in some way. Some of them accept the situation and the behaviors of the child really improve. But some parents can answer the situation with an approach like "but they are just little, it is very normal to talk."

"Not waiting their turns" is one of the challenging behaviors specified by another teacher (T8) under the theme of "accommodation problems". It was found that when she faces such a behavior, she uses positive (symbolic) reinforcement specifying that she uses a sticker to reduce this behavior gradually, and uses positive (social content) reinforcement specifying that she says "thank you" to any child when she sees that the child exhibits a proper behavior towards his/her friends, within the scope of the behavior modification based discipline approaches. The strategies of T8 mentioned here are given in the following expressions.

T8: Problems in the behaviors such as participating in a group without harming others, sharing toys, waiting their turns occur more at the beginning of the semester. At such times, when I realize their desirable behaviors I attach sticky notes on their collar as reinforcement sometimes, but I reduce the reinforcement gradually. When they learn how they should behave, the problem behaviors appear less. In this way, sometimes their social behaviors start to improve, as well. When I see a child helping his/her friend or sharing his/her toy, I thank to the child who exhibits this behavior and I say that I like this scene so much (The other part of the interview with this teacher is presented in the section of findings related to the behaviors in the theme of self-control inadequacies). 
In addition to this, one of the teachers (T10) highlighted the behaviors of "not following classroom rules" and "avoiding following instructions" exhibited by the children under the theme of "accommodation problems". It was detected that the teacher adopts three different strategies from the behavior modification based discipline approaches to compete with these behaviors. When these are evaluated, it can be said that she used negative symbolic reinforcement ensuring that the child sits on a cushion in a distinct place, accompanied by a sandglass, due to his/her challenging behavior; uses positive social content reinforcement ensuring that the child gets a stick on a board with a green (positive behavior), red (negative behavior), or yellow (neutral behavior) content in the classroom, according to his/her behavior; and uses positive social content reinforcement stamping a green (smiling face), red (sad face), or yellow (neutral face) in the notes file for that day according to the behaviors of the child. These cases are explained below.

T10: They sometimes exhibit the behavior of not following the classroom rules or avoiding following the instructions. For example, today a female student tried to start the microwave oven in the classroom, climbing on her chair. Climbing on the chair and playing with the microwave oven is not a proper behavior. In such cases, I want them to go to the seat on the cushion next to the door and I turn the sandglass upside down on the floor near them. In the meanwhile, I told her that her behavior is not proper, it is also dangerous for her, and I do not want her to do it ever again. She stayed there until the end of her time without objecting, then we talked about her behavior and she accepted the result of her behavior and went to her friends. Also there are a "green", a "red", and a "yellow" board in our classroom. There, green contains positive, red contains negative, and yellow contains negative behaviors. I place the sticks with photographs of each child on relevant section on the board at the end of the day according to their behaviors throughout the day. Then, at the end of the day, they evaluate their behaviors looking at the board. Further, I stamp a green (smiling face), red (sad face), or yellow (neutral face) in the notes file, which shows the classroom activities and is sent to the parents, on the page of that day of the month, indicating the color of the behavior board where the child is placed at the end of that day. Parents make an evaluation related to the day checking the notes file. Sometimes they request detailed information on that day regarding the situation in the file, calling or messaging me in the evenings. I share the situation with the parents by communicating them when they need.

Table 3. The strategies and discipline approaches adopted by the preschool teachers against the "self-control inadequacies" they face in their classrooms

\begin{tabular}{|c|c|c|}
\hline \multicolumn{3}{|c|}{ Challenging Behaviors Faced in the Classroom } \\
\hline Self-Control Inadequacies & Strategies & Discipline Approaches \\
\hline \multirow{6}{*}{ Fighting (T1) } & Active listening & $\begin{array}{l}\text { Effective communication } \\
\text { approach }\end{array}$ \\
\hline & $\begin{array}{l}\text { Motiving for practicing logical } \\
\text { results }\end{array}$ & Social discipline approach \\
\hline & Isolation & $\begin{array}{l}\text { Control approach(Reality } \\
\text { therapy) }\end{array}$ \\
\hline & $\begin{array}{l}\text { Positive communication to meet the } \\
\text { need }\end{array}$ & $\begin{array}{l}\text { Control approach(Reality } \\
\text { therapy) }\end{array}$ \\
\hline & $\begin{array}{l}\text { Use of positive (social content) } \\
\text { reinforcement }\end{array}$ & $\begin{array}{l}\text { Behavior modification based } \\
\text { discipline approach }\end{array}$ \\
\hline & Giving hints through actions & $\begin{array}{l}\text { Behavior modification based } \\
\text { discipline approach }\end{array}$ \\
\hline
\end{tabular}




\begin{tabular}{lll}
\hline \multirow{2}{*}{$\begin{array}{l}\text { Speaking too loudly/ } \\
\text { Shouting out (T5) }\end{array}$} & $\begin{array}{l}\text { Giving hints through vocal signs }+ \\
\text { body language(1) }\end{array}$ & $\begin{array}{l}\text { Behavior modification based } \\
\text { discipline approach }\end{array}$ \\
\cline { 2 - 3 } & $\begin{array}{l}\text { Giving hints through vocal signs }+ \\
\text { body language(2) }\end{array}$ & $\begin{array}{l}\text { Behavior modification based } \\
\text { discipline approach }\end{array}$ \\
\hline \multirow{2}{*}{$\begin{array}{l}\text { Not being able to participate in } \\
\text { a group without harming others } \\
\text { (T8) }\end{array}$} & $\begin{array}{l}\text { Use of positive (symbolic) } \\
\text { reinforcement }\end{array}$ & $\begin{array}{l}\text { Behavior modification based } \\
\text { discipline approach }\end{array}$ \\
\cline { 2 - 3 } & $\begin{array}{l}\text { Use of positive (social content) } \\
\text { reinforcement }\end{array}$ & $\begin{array}{l}\text { Behavior modification based } \\
\text { discipline approach }\end{array}$ \\
\hline \multirow{2}{*}{$\begin{array}{l}\text { Fighting/ } \\
\text { Pushing around each other (T8) }\end{array}$} & $\begin{array}{l}\text { Use of negative (symbolic) } \\
\text { reinforcement }\end{array}$ & \begin{tabular}{l} 
Use of preventive \\
messages' \\
\cline { 2 - 3 } discipline approach
\end{tabular} \\
\cline { 2 - 3 } & $\begin{array}{l}\text { Motiving for practicing logical } \\
\text { results }\end{array}$ & $\begin{array}{l}\text { Effective communication } \\
\text { approach }\end{array}$ \\
\hline
\end{tabular}

Table 3 provides the strategies and the discipline approaches used by the preschool teachers against the "self-control inadequacies" they face in their classrooms. In this scope, it was found that one of the teachers (T1) practices the effective communication approach in the form of active listening by keeping silent and letting the children explain the incident, and practices the social discipline approach asking them for thinking what to do/say when they fight with each other (motiving for practicing logical results). It was also observed that this teacher mainly refers to the isolation strategy under the body of the control approach in order for the child to accept his/her own behaviors by himself/herself and to learn to judge his/her behaviors, by means of keeping the child on the Happiness Chairs in order to make him/her quit the disrupter behavior. In addition to this, it is also notable that the teacher uses the control approach that suggests positive communication to meet the need, stating that the reason why the children exhibit problem behaviors may sometimes be due to the fact that they have a wish which they expect to be understood. Besides these, it was found that in order to reach the desirable behavior; the same teacher adopts the behavior modification based discipline approach by granting social content positive reinforcements when a proper behavior is exhibited (the teacher thanks to a child as the child apologizes to his/her friend). The following quotations obtained from the interview with $\mathrm{T} 1$ reveal such cases in detail below.

T1: Sometimes there are children who fight with each other among their friends. I go to them and try to talk about what has just happened. At this point, I keep silent and want them to tell me the incident, because even sharing their emotions can relax them. In such a case, I want them to think about what they can do and what they can tell their friends. Sometimes I send them to the places where they can get relaxed. There are "Happiness Chairs" in our institution, which can be used by each classroom. They are colored chairs, made of wood to fit the size of the children... We explain them that they can feel good sitting there; we use them often in case of any need. The children also like sitting there; we tell them that they can turn back to us when they feel calmed down. Sometimes it is necessary that more than one child should sit there; there is more than one chair. Anyway, they are usually less nervy while sitting there, and sometimes they can make peace with each other even just while sitting on the chair. Actually, the children of this age group sometimes can want to express a wish; if we can somehow tell them what they want or prevent them from having any problem in this sense, they can even solve the problems among each other. For example, someday I witnessed the conversation of two children between each other; one of them went up to the other and told "I think, 
you should apologize to me", and the other asked "why", and the answer was "you collapsed my car while coming here"; he just had made a car from wooden blocks... The other one soon went and checked, the car was collapsed and said "I am sorry, I did not see it", he sat there and the two children made a car from the wooden blocks. Then, I went up to the child for this behavior and thanked to him for apologizing to and helping his friend.

Similarly, it was observed that another teacher (T8) highlights the behavior modification based discipline approach using a negative symbolic reinforcement such as relocating pegs on red and green hat model against the "fighting/pushing around each other" behavior of the children, while it was found that she uses the strategies such as using the preventive "I messages" emphasized by the effective communication approach, indicating that the teacher is not happy to see the fighting behavior of the children, and then using the strategy of help implement logical results, which is one of the steps suggested by the social discipline approach, by motiving them to apologize. These are explained below.

T8: (This part comes after the section of the challenging behaviors related to accommodation of the interview with this teacher). Sometimes they fight among each other, or if there is anything they do not accept, they push around each other. We have red and green hat models in our classroom, and green represents the children who exhibit proper behaviors while red represents improper behaviors. We expect the wooden pegs on which the names of all children are written to be attached on the green one. If there is any child who disturbs his/her friends or who does not behave properly, I tell him/her that s/he should relocate his/her peg. Telling him/her to pick his/her peg from the green hat and to attach it to the red one means a warning to him/her. And they do not like to be in the other place. Sometimes I warn them like this, but sometimes I further indicate what the behavior that s/he should correct is. I indicate that I am not happy to see him/her fighting his/her friends, and s/he should apologize in such a case.

On the other hand, it was found out that one of the preschool teachers (T5) utilizes the behavior modification based discipline approaches such as turning up/down the lamp (giving hints through actions), singing a song (giving hints through vocal signs), and demonstrating the lyrics of the song by gestures (giving hints through body language) against the behavior of "speaking too loudly/shouting out". The cases are as follows:

T5: Sometimes they tend to start speaking too loudly/shouting out in the classroom. Turning up/down the lamp is very useful. It catches their attention, they become quiet; I often do it. Then, we can continue more quietly. Besides, I sing the song "Hands on your head. Eyes on me. If you are ready, say 1, 2, 3." When I start singing, they do what I say, sometimes by singing along with me and sometimes just by listening to me. And also I do it by demonstrating what to do, and then they pay better attention. And sometimes I sing the song "Give me five" until ensuring silence in the classroom. "Eyes-look, ears-listen, mouth-closed, hands-still, feetquiet." Most of the time they start doing the moves with me lowering their voices. Then, the rhythm of the song starts sounding, rather than a loud noise in the classroom. It is something that this age group enjoys so much, anyway... Sometimes they sing along the song, sometimes they just listen to it. And I sing the song by demonstrating, like "I have ears here and they hear you." That is to say, I try to tell them that I can hear them; there is no need to speak loudly. 
Table 4. The strategies and discipline approaches adopted by the preschool teachers against the "absence of prosocial behaviors" they face in their classrooms

Challenging Behaviors Faced in the Classroom

\begin{tabular}{|c|c|c|}
\hline Absence of Prosocial Behaviors & Strategies & Discipline Approaches \\
\hline \multirow{2}{*}{$\begin{array}{l}\text { Telling their wishes by crying } \\
\text { (T2) }\end{array}$} & $\begin{array}{l}\text { Explaining the } \\
\text { rules/expectations }\end{array}$ & Assertive discipline approach \\
\hline & $\begin{array}{l}\text { Positive communication to meet } \\
\text { the need }\end{array}$ & $\begin{array}{l}\text { Control approach(Reality } \\
\text { therapy) }\end{array}$ \\
\hline \multirow{2}{*}{ Not sharing toys (T8) } & $\begin{array}{l}\text { Use of positive (symbolic) } \\
\text { reinforcement }\end{array}$ & $\begin{array}{l}\text { Behavior modification based } \\
\text { discipline approach }\end{array}$ \\
\hline & $\begin{array}{l}\text { Use of positive (social content) } \\
\text { reinforcement }\end{array}$ & $\begin{array}{l}\text { Behavior modification based } \\
\text { discipline approach }\end{array}$ \\
\hline \multirow{2}{*}{$\begin{array}{l}\text { Having problems in sharing } \\
\text { (T9) }\end{array}$} & $\begin{array}{l}\text { Encouraging the child to } \\
\text { evaluate and change the } \\
\text { challenging behavior }\end{array}$ & $\begin{array}{l}\text { Control approach(Reality } \\
\text { therapy) }\end{array}$ \\
\hline & Isolation (time-out) & $\begin{array}{l}\text { Behavior modification based } \\
\text { discipline approach }\end{array}$ \\
\hline
\end{tabular}

According to Table 4, the preschool teachers adopt different strategies and discipline approaches against the challenging behaviors related to the prosocial development of the children in their classrooms. It is observed that one of the preschool teachers (T2), uses the assertive discipline approach that highlights explaining the behavior expected from the children indicating its reason by means of the expressions such as "you should tell it without crying, otherwise I cannot hear you well", against the behavior of "telling the wishes by crying" exhibited by the children. In addition to this, the same teacher mentions the use of a strategy to avoid any challenging behavior by meeting the needs of the children such as feeling valuable and being aware that they are listened to (feeling of importance, gaining acceptance). This strategy emphasizes the control approach (reality therapy), which suggests that the unsatisfied needs of the children can cause challenging behaviors. The following statement explains such cases.

T2: For example, there can be children who want something by crying. I tell them "I cannot here you well in this situation, I think I can here you better if you say it without crying." I lean to his/her height level and say "we can try if you say it now without crying". Then, sometimes some children laugh over it, and sometimes some children try to say something correct into my ear. In fact, sometimes the reason why they cry may be something different. If we give them the message of "I appreciate you, I am here, I am ready to listen to you”, we may face problem behaviors less.

According to the findings in the Table 4, both of the preschool teachers (T8, T9) face the "absence of prosocial behaviors" distinguished as "not sharing/having problems in sharing toys" in their classrooms and adopt certain strategies and discipline approaches against them. It was detected that one of the teachers (T8) uses the positive symbolic reinforcement and positive social content reinforcement for the behaviors such as following the rules of the classroom, waiting for his/her turn, and sharing his/her toys, upon reviewing the strategies and discipline approaches used by the teachers. Since it was determined that T8 uses similar strategies for several different behaviors, the exact quotations by this teacher are provided in the first part mentioned in the section above.

Nevertheless, it was found that another preschool teacher (T9) gives speeches for manipulating the cases such as making friends at the beginning of the semester and sharing their toys, to 
prevent the children from having problems; in other words, she adopts the preventive classroom management model. At the same time, it can be said that the teachers refer to the stages of the problem solving approach with the expressions such as "How do you think we can solve this issue?", "Let's try!", "Do you think this works?", "What else can be done?" / "Why do you think it did not work?", against the problem of sharing they face. Such cases show that T9 adopts the strategies for encouraging the children to evaluate and change the challenging behavior, suggested by the reality therapy against the challenging behaviors. In addition to this, it was found that the teachers applied the isolation (time-out) strategy emphasized by the behavior modification based discipline approaches by motiving the children, who exhibit problem behavior, to sit on the "soft-sofa" until they want to talk. The cases mentioned here can be seen in the expressions below.

T9: Preschool children just continue learning; therefore, it is very normal that they make mistakes... Sometimes they will learn by making mistakes. I do not consider every improper behavior I face in the classroom as a big problem. When I face any problem behavior, I get the message that s/he has not learned it yet and I think that I must give him/her an opportunity to make trials, so as to make him/her attain that behavior. We talk together especially on the situations such as how we should behave in the classroom, how we can be friends with each other, and how we can share our toys. But still, some students have problems in sharing sometimes. When such a problem occurs, I ask them "how do you think we can solve it?" Sometimes, I say "Let's try!" upon their comments, and I want them to see its result, if it is something we can try without getting harmed. Then I say, "Do you think this works?", "What else can be done?" or "Why do you think it did not work?" In the end, they might not yet know a behavior which the adults know how it should be. We have a place named "soft-sofa" which we use for a child who does not follow the rules, disturbs his/her friends, or feels bad, and I ask them to go there saying "It is obvious something has disturbed you. Would you like to think about it here?." I do not send the same child there frequently; after all, the time-out concept is a method of punishment at the same time. But it is a good option for them to think and speak when they feel ready. I wait until they want to speak, then I say "I am ready to listen to you when you are ready to talk." Anyway, they start talking when they are ready to speak.

Table 5. The strategies and discipline approaches adopted by the preschool teachers against the "deficiencies in the assertiveness skill" they face in their classrooms

\begin{tabular}{lll}
\hline Challenging Behaviors Faced in the Classroom & \\
\hline $\begin{array}{l}\text { Deficiencies in the Assertiveness } \\
\text { Skill }\end{array}$ & Strategies & Discipline Approaches \\
\hline $\begin{array}{l}\text { Remaining passive in the classroom } \\
\text { (T4) }\end{array}$ & Motivation and encouraging & Social discipline approach \\
\hline $\begin{array}{l}\text { Never asking for permission to } \\
\text { speak (T4) }\end{array}$ & Motivation and encouraging & Social discipline approach \\
\hline $\begin{array}{l}\text { Hesitating to participate in plays } \\
\text { (T4) }\end{array}$ & $\begin{array}{l}\text { Motivation and } \\
\text { encouragement }\end{array}$ & Social discipline approach \\
\cline { 2 - 3 } & Social engineering & Social discipline approach \\
\hline
\end{tabular}

As Table 5 shows, it was detected that only one of the preschool teachers (T4) emphasizes the "challenging behaviors related to assertiveness" which appears as "remaining passive in the classroom/never asking for permission to speak/hesitating to participate in his/her friends' play" in the classroom. Considering the strategies and discipline approaches used for competing with 
such challenging behaviors, it was observed that they adopt similar cases for the children who exhibit passive behaviors and who do not ask for permission to speak. Within this framework, it was determined that they prefer the door-opener approach, in which the expressions such as "Come on, you can tell it, too!"/“I want to listen to you, too/You can also tell something" for the children "who remain passive/never ask for permission to speak" are used. At this point, it was determined that the motivation and encouragement strategy, which falls into the scope of the social discipline approach, is emphasized, highlighting the positive characteristics and emphasizing the efforts of the children. In addition to this, it was determined that the motivation and encouragement skill, which falls into the scope of the social discipline approach, is activated by means of an expression such as "Well, at first you can watch the play of your friends, you can see what they are doing, and when you want to join them, you can tell them that you want to play with them", and then by counting with the children the number of the persons in the play group in which the child wants to join, for the children who hesitate to participate in the plays of their friends. Besides, it is also observed that the same teacher emphasizes the use of the social engineering skill along with the motivation and encouragement skill, which falls into the scope of the social discipline approach, helping the children come together by means of the expressions such as "your friend wants to join in the play in your group" / "This friend can support your play" in order to make the children, who are in the play group in which the child who hesitates to participate, let him/her join in the play. The quotations obtained from the interview with T4 provided below explain such cases.

T4: There can be some children who remain passive or who never ask for permission to speak in the classroom sometimes. When I realize that certain children always keep silent, I personally ask them "what do you think", saying their names. I ask them to speak by saying something like "Come on, you can tell it, too!" or "I want to listen to you, too, I am sure you can also say something". Sometimes, shier children have difficulty in joining their friends' plays. In such cases, I tell the child "Well, at first you can watch the play of your friends, you can see what they are doing, and when you want to join them, you can tell them that you want to play with them." If s/he still has difficulty in joining the game, I ask him/her "which play group would you like to join in? Let's see how many people there are"; then we count the number of the children in the group they want to play, sometimes we go together to the children in the group and then s/he joins in that group. And sometimes I tell the group "your friend wants to join in the play in your group", "This friend of you can support your play." Sometimes the children can have difficulties in joining in the group, but once they join in the group, they can do a good job together.

\section{Discussion and Recommendations}

Evaluating the opinions of the preschool teachers on the most frequent challenging behaviors they face in their classrooms, it was determined that the behaviors of telling their wishes by crying (T2), speaking by interrupting others (T3), remaining passive/not asking for permission to speak/hesitating to participate in plays (T4), speaking too loudly/shouting out (T5), pushing around each other/participating in a group harming others/not waiting their turns (T8), not following classroom rules/avoiding following classroom instructions (T10) were reported as the challenging behaviors, while fighting (T1, T8), talking among themselves/not focusing on their studies (T6, T7), and not sharing (T8, T9) were reported to be partially more. Remarkably, the challenging behaviors asserted to be faced by the teachers are the behaviors occurring under the theme of "accommodation problems", "self-control inadequacies", 
"absence of prosocial behaviors", and "deficiencies in assertiveness skill". Analyzing these behaviors according to their themes; it was observed that the challenging behaviors under the theme of "accommodation problems" are the most frequently mentioned ones (6 teachers), followed by the challenging behaviors under the theme of "self-control inadequacies" (5 teachers). Following these, the challenging behaviors under the theme of "absence of prosocial behaviors" and the behaviors under the theme of "deficiencies in assertiveness skill" were reported equally ( 3 teachers). In this scope, it was found that 15 different challenging behaviors were emphasized in total by the teachers in the study during the interviews. While it was observed that one of the teachers (T4) highlights the internalizing behaviors in the form of remaining passive/not asking for permission to speak/hesitating to participate in games among the most frequent challenging behaviors faced in their classrooms by the preschool teachers in the study group, it is remarkable that predominantly externalizing behaviors are mentioned. The fact that the externalizing challenging behaviors can be observed directly in the classroom environment might have an impact on this case. From another perspective, this case may be associated with the fact that externalizing behaviors are more damaging than internalizing behaviors. This case is parallel with the results of the study conducted on the children of different stages towards challenging behaviors (Borg \& Falzon, 1989; Dal \& Akan, 2018; Merrett \& Wheldall, 1984; Tulley \& Chiu, 1995; Yagan Güder, Alabay \& Güner, 2018). In this sense, the expression by T4 suggesting that deficiency in assertiveness skill is a challenging behavior is a result catching attention to the challenging behaviors that are less mentioned in the field.

Evaluating the results specified here with regards to the first sub-goal obtained from the study, it can be said that the most frequent challenging behaviors faced by the preschool teachers in their classrooms are similar to the results of the relevant studies in the literature in general. It is specified in the study by Hayes (2007) that behaviors such as tantrum, disobedience, fighting, lying, theft, disrespect, restlessness, inability to focus, lack of attention, and behaving recklessly are faced during the preschool period, differing depending on the gender of the children. It was found as a result of a study conducted in Turkey that the most frequent problem behaviors faced by preschool teachers include lying, problems in eating habit, anxiety of separation, jealousy, speech disorders, stubbornness, aggression, and nail-biting behaviors (Ikiz, Mete Otlu, \& Ekinci Vural, 2016). According to the study by Yagan Güder, Alabay, \& Güner (2018), the most frequent behavioral problems faced by preschool teachers are tantrum, crying, shouting, and stubbornness. In another recent study, preschool teachers define behaviors such as not following classroom rules, complaining, use of violence, not joining in activities, not sharing, not minding teacher, hyperactivity, lack of attention, and crying for no reason as challenging behaviors (Dal \& Akan, 2018). Although the challenging behaviors specified in the national and international literature might vary, outcomes of the studies point out that the behaviors stated to be challenging behaviors are disturbing, damaging, and obstructive for interpersonal relations and academic processes, threatening development in the general framework. On the other hand, these cases are an expression of the fact that challenging behaviors are a universal phenomenon faced in the field of preschool education.

Analyzing the strategies and discipline approaches used by the preschool teachers against the challenging behaviors within the scope of the theme of "accommodation problems", it is revealed that the behavior modification based discipline approaches are used predominantly, while several different strategies were found, as well. Within this scope, it was found that besides the strategies such as giving hints by body language/vocal signs, they mainly use positive symbolic or positive social content reinforcements as well, and they highlight negative symbolic reinforcement only in one form. Within this framework, the instructional approach 
and the control approach are adopted against the behavior of "talking among each other/inability to focus on their studies", while the assertive discipline approach is also utilized. At this point, it is observed that one of the teachers (T7) uses the sanction of inviting the family to the school, which comprises the strategy of determining logical sanctions, and reflects it saying "when some of the talkative children's mothers visit the school, they talk to the teacher for hours and in some way when the situation is shared with the family, the children of the families who accept the situation improve their behaviors but when the family does not accept the change, the change in the child occurs later, too". This situation in the expression of the teacher indicates that the challenging behaviors observed in classroom are under the impact of the characteristics of the families. This situation is supported by the findings suggesting that the behavioral problems of the preschool children are associated with the attitudes of the parents and the relationship between the parents and children (Aunola \& Nurmi, 2005; Brook, Lee, Finch, \& Brown, 2012; Criss, Pettit, Bates, Dodge, \& Lapp, 2002; Kerr, Lopez, Olson, \& Sameroff, 2004; Livanage, Prince, \& Scott, 2003; Topçu Bilir \& Sop, 2016). Cipani (1998) argues that maximum benefit must be obtained from educational opportunities, suggesting that accommodation is beneficial for the preschool children in academic, behavioral, social, and emotional terms. In a study (Dal \& Akan, 2018) determining that the most frequent challenging behavior is specified by the teachers as not following the classroom rules emphasizes the requirement of addressing the behaviors in the scope of the accommodation problems. Therefore, as highlighted by Feil et al. (2014), adopting home-school based interventions against the challenging behaviors in the preschool children can also be an efficient method. The strategy of determining logical sanction requires that teachers implement a series of several sanctions to be implemented against the improper behaviors of the children. Within this framework, it was revealed that one of the teachers in the study tried a solution based on collaboration against the behavior of speaking too much, and consulted the family for their support.

At the same time, it was detected that the behavior modification based discipline approaches are highlighted against the behaviors of speaking by interrupting/not waiting their turns/not following classroom rules/avoiding following classroom instructions, fighting/pushing around each other, speaking too loudly/shouting out, inability to joining in a group without harming others, and not sharing. This approach, suggesting mainly the use of certain positive-negative reinforcements and punishments for behavior modification, comprises strategies such as determining classroom rules, using positive/negative reinforcement, making an agreement, taking model, giving hints through actions/signs, taking privileges back, and punishing. However, the permanence of this approach weakens in case no limitation is set to rewards and in case of the use of over-control. In this sense, it can be said that this easy to use approach is preferred by the teachers who tend to keep the behavior under control (Edwards, 1993). It is emphasized in a study conducted in the province of Igdir-Turkey that preschool teachers try to compete with the challenging behaviors by practicing reward and reinforcement at the most. This suggests that certain preschool teachers tend to use behavior modification based discipline approaches against the challenging behaviors. Behaviors such as behaving aggressively, objection, and harming are the typical problem behaviors observed in the preschool classrooms (Bear, Cavalier \& Manning, 2002). Teachers should be promoted to adopt more functional strategies with regards to the prevention of challenging behaviors occurring due to self-control inadequacy.

It was detected that teachers adopt many different strategies such as active listening, motiving for practicing logical results, isolation, positive communication to meet the need, use of positive (social content) reinforcement and negative (symbolic) reinforcement, use of preventive 'I 
messages' against the behavior of fighting. It was also revealed that along with these strategies, different practices within the scope of effective communication approach, social discipline approach, control approach, and behavior modification based discipline approach are also adopted. One of the reasons for this might be that the behavior of fighting is a behavior that absolutely must be prevented; it might lead the teachers to use different strategies. That being the case, it is also a positive situation when teachers exhibit punishing, criticizing, or accusing attitudes. For example, it was observed that in the isolation method adopted by a teacher, the children are sent to a colored system built in the size of the children and in the name of "Happiness Chairs", a place even where when they are placed at, they can feel relaxed and think about the issue. This suggests that the teachers try to adopt some sort of moderate communication in the process of coping with the challenging behaviors. Culp, Howell, Culp \& Blankemeyer (2001) found that the behaviors of the teachers towards the children in the preschool period have an impact on the problem behaviors of the children. In this sense, it is desirable that the study contains findings suggesting that teachers communicate with the children within the framework of the effective discipline approaches. The findings by Katsuyuki \& Noriko (2009) arguing that the behavior of aggression impacts even the number of the friends of a child remark the importance of the discipline approaches related to eliminating such kind of behaviors.

As another result obtained from the study; it was detected that the teachers predominantly use the strategies within the scope of the behavior modification based approach and control approach, while one of the teachers adopts the assertive discipline approach in this scope, when the prominent behaviors within the scope of the absence of prosocial behaviors such as telling wishes by crying and not sharing are exhibited. The fact that the teacher says "If we give them the message of 'I appreciate you, I am here, I am ready to listen to you', we may face problem behaviors less" within the scope of the assertive discipline approach is an expression of the opinion that suggests it is possible to eliminate negative behaviors by means of ensuring sensitivity for the needs of the children and meeting their needs. Dobbs, Arnold \& Doctoroff (2004) found that the challenging behaviors observed in the preschool children are significantly associated with the attention of the teacher, which is an example for this case.

On the other hand, it is remarkable that one of the teachers (T4) in the research specifies behaviors such as remaining passive in the classroom, never asking for permission to speak, and hesitating to join in plays as challenging behaviors. In other words, this teacher considers the children's behaviors of active participation, requesting permission to speak when required, and joining in the plays of their friends easily when they wish as desirable behaviors that should be exhibited in the classroom. This opinion, which comprises the behaviors in the assertiveness dimension, highlights the behaviors that are not healthy on the individual basis, unlike the directly harming or disturbing behaviors in the scope of the challenging behaviors. Within this context, it was found in the relevant literature studies that a behavior can be named as an challenging behavior basing on the fact that it produces a negative effect on the personal/social development of a child, rather than creating a physical/psychological danger to the child or to his/her environment or damaging the environment materially, being not widely observed, though. On the other side; such a finding that is revealed by a limited number of teachers in the study conducted in the United States has not been obtained widely in the studies conducted in Turkey (e.g., Dal \& Akan, 2018; Ikiz, Mete Otlu, \& Ekinci Vural, 2016; Yagan Güder, Alabay, \& Güner, 2018), which suggests there can be a difference in the cultural expectations/point of view. As the self-respect and self-confidence of the children who have problems in expressing themselves and who behave introverted will be at danger, it comes to light once more that such kind of behaviors exhibited by the children must be emphasized highly. Analyzing the strategies 
and discipline approaches used by this teacher; it is a dramatic finding that she practices motivation and encouragement skills and social engineering skill in the scope of the social discipline at this point. According to Dreikurs, motivation and encouragement should be concentrated on instead of reward and reinforcement, which cause dependency and provoke focusing on the result. The process named social engineering highlights revealing the inadequate skills of the children, at the same time ensuring that the children obtain positive experiences in time. At this point, it is important that the children come together and make contact with each other with their own efforts (Wofgang, 1995). Here, the teacher (T4) motivates the children to help each other by means of expressions such as "Your friend wants to join in the play in your group, too", "This friend can support your play". In a study conducted in Turkey sample (Buyuktaskapu Soydan et al., 2018), it was emphasized that the majority of the preschool teachers adopt controller discipline and discipline based on obedience against the problem behaviors. The study by Akgün, Yarar, \& Dincer (2011) based on the supervision performed by preschool teachers in classroom environment showed that teachers practice the negative classroom management strategies more. Since adopting such a discipline understanding against the behaviors of the children has an impact on highlighting the characteristics such as shyness, introversion, and timidity, there is a need for the efforts to improve the strategies and approaches in this scope.

In this case, in different studies (such as Buyuktaskapu Soydan et al., 2018; Sesli \& Bozgeyikli, 2015), it was found that the discipline approaches of preschool teachers are predicted by variables such as professional seniority, problem solving skills, love for children, the type of the school they work at, and the type of the school they were graduated from. Basing on this, the reason why the strategies used by the teachers against the challenging behaviors can be also explained by the fact that they are affected by different variables. For example, Luo, Bellows \& Grady (2000) found that teachers with less experience have problems in competing with the behavioral problems. Another study (Polat, Arslan \& Sat1c1, 2016) suggested that teachers with good attitudes towards the profession of teaching build a more democratic classroom climate, valuing the students more and taking the students in the center. Hiralall \& Martens (1998) found that the training delivered to preschool teachers on teaching classroom management skills contributes to the teachers to use more educational expressions and modellings. Thus, it is a must to improve the relevant knowledge, skills, and experiences of the teachers to minimize the impact of the variables that can negatively affect the skills of the teachers to compete with the challenging behaviors.

In a study conducted in the Turkey sample, Sadik (2004) determined that preschool teachers tend to give orders to children with expressions such as "sit down, be quiet, mind your study, and do not complain" loudly, when they face challenging behaviors. The study by Akgün, Yarar, \& Dinçer (2011) conducted in the province of Ankara revealed that preschool teachers adopt the reactive model against challenging behaviors. Remarkably, Uysal, Akbaba Altun, \& Akgün (2010) determined that preschool teachers mostly practice strategies such as reminding the rules, asking questions, warning by name, warning by signs, making eye contact, acting physical closeness, remaining silent, and warning by touching, as well as scolding and intimidating. Yagan Güder, Alabay, \& Güner (2018) also suggested that preschool teachers frequently practice methods such as making eye contact, ignoring, and punishing against problem behaviors. Another study (Karabay \& Asi, 2015) asserted that preschool teachers tend to use the reward system and explain the necessity of the rules, and as well as use the punishment system, in order to ensure adoption of the rules. A recent study (Medikoglu, \& Dalaman, 2018), in which the opinions of teachers with different fields of specialty extending from preschool teachers to branch teachers, emphasized that teachers use strategies of warning, 
ignoring, rewarding and punishing, and sending to guidance service. These results indicate that efficient classroom management strategies are not practiced and the knowledge and experiences of teachers are needed to be improved to create a warm classroom environment.

On the other hand, as a result of this study which was conducted in the United States sample, it was revealed that teachers adopt many proper strategies such as the use of preventive "Imessages", explaining rules and expectations, and the use of positive communication to meet the need. Similarly, in a study by Ritz, Noltemeyer, Davis \& Green (2014) conducted in the Midwest States, it was determined that teachers not only adopt reactive strategies such as repeating the instructions, taking breaks, offering a choice, using a behavior graph, and ignoring, but also they adopt preventive strategies such as giving positive feedback, reviewing the rules regularly, informing about transition, notifying the instructions when needed, and explaining the instructions regarding the issues rather than the questions. These suggest that there are partial differences in the strategies used in Turkey and in the United States to cope with challenging behaviors. In the study by Turnuklu (2000), which compares Turkey and England in terms of management of student behaviors and organization of the classroom order, certain differences were revealed. According to this, it was concluded that noise and speaking without permission are challenging behaviors for both countries, while it was highlighted that classroom management is ensured by means of traditional method in Turkey. Akin Little, Little, \& Laniti (2007), analyzing the classroom management practices of teachers in the United States and in Greece, concluded that effective classroom management strategies are highly used in both of these countries. In this line, it was concluded that preschool teachers are highly important in terms of not only the strategies followed by them against the challenging behaviors of children, but also the discipline approaches they adopt. In accordance with the results obtained from the study, the following recommendations can be suggested for the experts of the field, teachers, and researchers.

It is required to ensure that the strategies of teachers for competing with challenging behaviors are positively improved and ensure them to adopt effective discipline approaches. In this process, the knowledge, skills, and experiences of preschool teachers in the dimension of classroom management should be improved. It would be a primary contribution if the field experts deliver lessons equivalent to the lessons such as Classroom Management, School Experience, and Teaching Practice, conducted in the Undergraduate Program of Preschool Education Department. It is recommended to give information on the strategies and approaches to compete with challenging behaviors by means of activities such as seminars, conferences, and workshops to be organized throughout regions, or by means of training seminars provided within the body of the relevant ministries. By means of ensuring the cooperation and support by institutions such as Ministry of National Education, Non-governmental Organizations, and Universities, various persons and institutions should be supported to perform their share of responsibilities for eliminating challenging behaviors of the children.

In this study, the findings related to the challenging behaviors exhibited by the preschool children were obtained in accordance with the opinions of the preschool teachers. For the future studies, the process of multiple data collection can be carried out, accompanied by the observations to be performed by the researcher, along with interviews. The impact of the different strategies and discipline approaches on challenging behaviors can be demonstrated by longitudinal studies. This is a study conducted in the sample of the United States. In other studies, transnational/ interregional comparative researches on what challenging behaviors are and how they are tried to be analyzed can be performed; experimental studies can be conducted to reduce challenging behaviors through different practices. In this framework, efforts should 
be made to eliminate challenging behaviors in the early years as far as possible by means of effective methods and strategies.

\section{References}

Akgün, E., Yarar, M. \&, Dincer, Ç. (2011). The evaluation of classroom management strategies of preschool teachers in classroom activities. Pegem Journal of Education and Instruction, 1(3), 1-9.

Akin Little, K. A., Little, S. G., \& Laniti, M. (2007). Teachers' use of classroom management procedures in the United States and Greece: A cross-cultural comparison. School Psychology International, 28(1), 53-62.

Aksoy, P. (2018). Duygusal ve davranışsal bozukluğu olan çocuklar ve eğitim sorunları [Children with emotional and behavioral disorders and educational problems]. In Z. Seçer (Ed.), Risk altındaki çocuklar [Children at risk], (pp. 279-312). Ankara: Egiten Publications.

Aunola, K. \& Nurmi, J. E. (2005). The role of parenting styles in children's problem behavior. Child Development, 76(6), 1144-1159.

Aygün, A., Yildizbas, F. \& Aygün, B. (2014). Determination of the difficulties that pre-school teachers face with classroom management. Procedia-Social and Behavioral Sciences, $143,758-763$.

Basten, M., Tiemeier, H., Althoff, R. R., van de Schoot, R., Jaddoe, V. W. V., Hofman, A., Hudziak, J. J., Verhulst, F. C., \& van der Ende, J. (2016). The stability of problem behavior across the preschool years: An empirical approach in the general population. Journal of Abnormal Child Psychology, 44(2), 393-404.

Bear, G. G., Cavalier, A. R., \& Manning, M. A. (2002). Best practices in school discipline. In A. Thomas \& J. Grimes (Eds.), Best practices in school psychology (4 ${ }^{\text {th }}$ edition), (pp. 977 - 991). Bethesda, MD: National Association of School Psychologists.

Borg, M. G. \& Falzon J. M. (1989). Primary school teacher' perception of pupils' undesirable behaviours. Educational Studies, 15(3), 251-260.

Bredekamp, S. (2016). Effective practices in early childhood education: Building a foundation ( $3^{\text {rd }}$ edition). Upper Saddle River, NJ: Pearson Education.

Brook, J. S., Lee, J. Y., Finch, S. J., \& Brown, E. N. (2012). The association of externalizing behavior and parent-child relationships: An intergenerational study. Journal of Child Family Studies, 21(3), 418-427.

Buckwalter, K. D., Reed, D. \& Sunshine, W. L. (2020). Raising the challenging child: How to minimize meltdowns, reduce conflict, and increase cooperation. United States: Baker Publishing Group.

Bulotsky Shearer, R. J., Fernandez, V., Dominguez, X., \& Rouse, H. L. (2011). Behavior problems in learning activities and social interactions in head start classrooms and early reading, mathematics, and approaches to learning. School Psychology Review, 40(1), 39-56.

Buyuktaskapu Soydan, S., Alakoc Pirpir, D., Ozturk Samur, A., \& Angin, D. A. (2018). Preschool teachers' classroom management competency and the factors affecting their understanding of discipline. Eurasian Journal of Educational Research, 18(73), 149172.

Canter, L. \& Canter, M. (1992). Lee Canters's assertive discipline. Santa Monica: Canter \& Associates Inc.

Cipani, E. (1998). Three behavioral functions of classroom noncompliance: Diagnostic and treatment implications. Focus on Autism and Other Developmental Disabilities, 13(2), 66-72. 
Couchenour, D. \& Chrisman, J. K. (2016). The SAGE Encyclopedia of contemporary early childhood education (Vol 1). Thousand Oaks, California: SAGE Publications, Inc.

Creswell, J. W. (2009). Research design: Qualitative, quantitative, and mixed methods approaches ( $3^{\text {rd }}$ edition). Thousand Oaks, CA: Sage Publications.

Creswell, J. W. (2012). Educational research: Planning, conducting, and evaluating quantitative and qualitative research ( $4^{\text {th }}$ edition). Upper Saddle River, NJ: Pearson/Merrill Prentice Hall.

Criss, M. M., Pettit, G. S., Bates, J. E., Dodge, K. A., \& Lapp, A. L. (2002). Family adversity, positive peer relationships, and children's externalizing behavior: A longitudinal perspective on risk and resilience. Child Development, 73(4), 1220-1237.

Culp, R. E., Howell, C. S., Culp, A. M., \& Blankemeyer, M. (2001). Maltreated children's emotional and behavioral problems: Do teachers and parents see the same things?. Journal of Child and Family Studies, 10(1), 39-55.

Cutter Mackenzie, A., Edwards, S., Moore, D. \& Boyd, W. (2016). Young children's play and environmental education in early childhood education. Australia: Springer.

Dal, M. \& Akan, D. (2018). Okul öncesi öğretmenlerinin öğrencilerin istenmeyen davranışlarıyla baş etmede kullandıkları sınıf yönetimi stratejileri [Classroom management strategies used to deal with unwanted behaviors encountered by pre-school teachers]. Journal of Human Sciences, 15(2), 1116-1128.

Denzin, N. K. \& Lincoln, Y. S. (2011). Introduction: The discipline and practice of qualitative research. In N. K. Denzin \& Y. S. Lincoln (Eds.), The Sage handbook of qualitative research ( ${ }^{\text {th }}$ edition), (pp. 1-19). Thousand Oaks, CA: Sage Publications.

DiGennaro, F. D., Martens, B. K., \& Kleinmann, A. E. (2007). A comparison of performance feedback procedures on teacher's implementation integrity and students' inappropriate behaviour in special education classrooms. Journal of Applied Behavior Analysis, 40(3), 447-461.

Dobbs, J., Arnold, D. H., \& Doctoroff, G. L. (2004). Attention in the preschool classroom: The relationships among child gender, child misbehavior, and types of teacher attention. Early Child Development and Care, 174(3), 281-295.

Edwards, C. H. (1993). Classroom discipline and management. New York: Macmillan Publishing Company.

Ellis, L. (2018). Teachers' perceptions about classroom management preparedness. Unpublished Doctorate Thesis, Walden University College of Education, Minneapolis, MN.

Feil, E. G., Frey, A., Walker, H. M., Small, J. W., Seeley, J. R., Golly, A., \& Forness, S. R. (2014). The efficacy of a home-school intervention for preschoolers with challenging behaviors: A randomized controlled trial of preschool First Step to Success. Journal of Early Intervention, 36(3), 151-170.

Glasser, W. (1992). The quality school: Managing students without coercion ( $2^{\text {nd }}$ edition). New York: Harper-Perennial.

Gülay Ogelman, H. \&, Ersan, C. (2014). Okul öncesi öğretmenlerinin sınıf yönetimi stratejilerinin çocukların akran ilişkileri üzerindeki etkisi [The effect classroom management strategies for preschool teachers has on peer relationships in children]. Bartin University Journal of Faculty of Education, 3(2), 63-84.

Hayes, L. (2007). Problem behaviours in early primary school children: Australian normative data using the strengths and difficulties questionnaire. Australian and New Zealand Journal of Psychiatry, 41(3), 231-238.

Hiralall, A. S., \& Martens, B. K. (1998). Teaching classroom management skills to preschool staff: The effects of scripted instructional sequences on teacher and student behavior. School Psychology Quarterly, 13(2), 94-115. 
Honig, A. S. (1997). Behavior guidance for infants and toddlers. Little Rock, AR: Southern Early Childhood Association.

Ikiz, F. E., Mete Otlu, B., \& Ekinci Vural, D. (2016). Erken çocukluk döneminde görülen problem davranışlar: Öğretmenlerin değerlendirmesi [Problem behaviours seen in early childhood: The teachers' consideration]. Mehmet Akif Ersoy University Journal of Social Sciences Institute, 8(17), 216-229.

Johansen, A., Little, S. G., \& Akin Little, A. (2011). An examination of New Zealand teachers' attributions and perceptions of behaviour, classroom management and the level of formal teacher training received in behaviour management. Kairaranga, 12(2), 3-12.

Jolivette, K. \& Steed, E. A. (2010). Classroom management strategies for young children with challenging behavior within early childhood settings. NHSA Dialog: A Research-toPractice Journal for the Early Childhood Field, 13(3), 198-213.

Jones, V. F. \& Jones, L. S. (2007). Comprehensive classroom management, creating communities of support and solving problems ( $8^{\text {th }}$ edition). USA: Allyn \& Bacon Company.

Karabay, S. O. \& Asi, D. Ş. (2015). Classroom rules used by preschool teachers and children's levels of awareness relating to rules. Inonu University Journal of the Faculty of Education, 16(3), 69-86.

Katsuyuki, Y. \& Noriko, N. (2009). The relationship between three types of aggression and peer relations in elementary school children. International Journal of Psychology, 44(3), 179-186.

Keane, S. P. \& Calkins, S. D. (2004). Predicting kindergarden peer social status from toddler and preschool problem behavior. Journal of Abnormal Child Psychology, 32(4) 409423.

Kerr, D. C. R., Lopez, N. L., Olson, S. L., \& Sameroff, A. J. (2004). Parental discipline and externalizing behavior problems in early childhood: The roles of moral regulation and child gender. Journal of Abnormal Child Psychology, 32(4), 369-383.

Kremer, K. P., Flower, A., Huang, J., \& Vaughn, M. G. (2017). Behavior problems and children's academic achievement: A test of growth-curve models with gender and racial differences. Children and Youth Services Review, 67, 95-104.

Lavigne, J. V., Gibbons, R. D., Christoffel, K. K., Arend, R., Rosenbaum, D., Binns, H. J., Dawson, N., \& Isaacs, C. (1998). Prevalence rates and correlates of psychiatric disorders among preschool children. Journal of the American Academy of Child and Adolescent Psychiatry, 35(2), 204-214.

Levin, J. \& Nolan, F. (2007). Principles of classroom management: A professional decisionmaking model. Boston, MA: Pearson-Allyn and Bacon.

Livanage, K. C., Prince, M. J., \& Scott, S. (2003). Mother-child joint activity and behaviour problems of preschool children. Journal of Child Psychology Psychiatry, 44(7), 1037 1048.

Luo, J., Bellows, L., \& Grady, M. (2000). Clasroom management issues for teaching assistants. Researh in Higher Education, 41(3), 353-383.

McCabe, L. A. \& Frede, E. C. (2007). Challenging behaviors and the role of preschool education. New Brunswick: National Institute for Early Education.

Medikoglu, O. \& Dalaman, O. (2018). Öğretmenlerinin derste karşılaştıkları istenmeyen öğrenci davranışları ve bu davranışlara yönelik çözüm stratejileriyle ilgili öğretmen görüşlerinin belirlenmesi [Unsolicited student behaviors relating to teachers' dereference and determination of teacher opinions related to solution strategies for such behavior]. Journal of Education, Theory and Practical Research, 4(1), 20-32.

Merrell, K. W. (2003). Preschool and kindergarten behavior scales ( $2^{\text {nd }}$ edition). Austin, TX: PRO-ED. 
Merrett, F. \& Wheldall, K. (1984). Classroom behavior problems which junior school teachers find most troublesome. Educational Studies, 10(2), 87-92.

Miles, M. B. \& Huberman, A. M. (1994). An expanded sourcebook: Qualitative data analysis. Thousand Oaks, CA: Sage Publications.

Miller, S., Smith Bonahue, T. \& Kemple, K. (2017). Preschool teachers' responses to challenging behavior: The role of organizational climate in referrals and expulsions. International Research in Early Childhood Education, 8(1), 38-57.

Morris, R. J., Shah, K., \& Morris, Y. P. (2002). Internalizing behavior disorders. In K. L. Lane, F. M. Gresham, \& T. E. O'Shaughnessy (Eds.), Interventions for children with or at risk for emotional and behavioral disorders (pp. 23-241). Boston, MA: Allyn \& Bacon.

Oztürk, Y. \& Gangal, M. (2016). Okul öncesi eğitim öğretmenlerinin disiplin, sınıf yönetimi ve istenmeyen davranışlar hakkındaki inançları [Preschool teachers' beliefs about discipline, classroom management, and disruptive behaviors]. Hacettepe Üniversitesi Ĕ̈itim Fakültesi Dergisi (H. U. Journal of Education), 31(3), 593-608.

Parsonson, B. (2012). Evidence-based classroom behaviour management strategies. Kairaranga, 13(1), 16-23.

Patton, M. Q. (2002). Qualitative research \& evaluation methods. London: Sage Publications.

Polat, S., Arslan, Y., \& Satıcı, A. (2016). Öğretmenlerin mesleki tutumları ile sınıf disiplin modeli tercihleri arasındaki ilişki [The relationship between teachers' attitudes towards teaching profession and classroom discipline model preferences]. Gazi University Journal of Gazi Educational Faculty (GUJGEF), 36(3), 675-691.

Powell, D., Fixsen, D., \& Dunlap, G. (2003). Pathways to service utilizations: A synthesis of evidence relevant to young children with challenging behavior. Tampa, FL: University of South Florida, Center for Evidence-Based Practice: Young Children with Challenging Behavior.

Reinke, W. M., Lewis Palmer, T., \& Merrell, K. (2008). The classroom check-up: A class wide teacher consultation model for increasing praise and decreasing disruptive behaviour. School Psychology Review, 37(3), 315-332.

Ritz, M., Noltemeyer, A., Davis, D., \& Green, J. (2014). Behavior management in preschool classrooms: Insights revealed through systematic observation and interview. Psychology in the Schools, 51(2), 181-197.

Sadık, F. (2004). Okul öncesi sınıflarda gözlenen problem davranışlar ve bu davranışlarla baş etmede öğretmenlerin kullandıkları yöntemler [Problem behaviors observed in preschool classrooms and methods used by teachers to deal with these behaviors]. Journal of Educational Research, 13, 89-97.

Sesli, S. \& Bozgeyikli, H. (2015). Okul öncesi öğretmenlerinin problem çözme becerileri ile disiplin anlayışlarının incelenmesi [The examination of preschool teachers' problem solving skills and their understanding of disciplinary]. OPUS- Türkiye Sosyal Politika ve Çalışma Hayatı Araştırmaları Dergisi (International Journal of Society Researches), 5(8), 82-111.

Shaw, D.S., Winslow, E. B., Owens, E. B., Vondra, H. I., Cohn, J. F., \& Bell, R. Q. (1998). The development of early externalizing problems among children from low-income families: A transformational perspective. Journal of Abnormal Child Psychology, 26(2), 95-107.

Tincani, M. (2011). Preventing challenging behavior in your classroom: Positive behavior support and effective classroom management. Waco, TX: Prufrock, Press.

Topcu Bilir, Z. \& Sop, A. (2016). Okul öncesi dönemindeki çocukların aile ilişkileri ile çocuklarda görülen davranış problemleri arasındaki ilişkinin incelenmesi [Investigation of the relationship between children's family relationships during preschool period and 
behavioral problems in children]. Mehmet Akif Ersoy University Journal of Education Faculty, 1(40), 20-43.

Tulley, M. \& Chiu, L. H. (1995). Student teachers and classroom discipline. The Journal of Educational Research, 88(3), 164-171.

Turnuklu, A. (2000). Türk ve İngiliz ilköğretim öğretmenlerinin sınıf içi davranış yönetim stratejilerinin karşılaştırılması [Comparison of classroom behaviour management strategies of Turkish and British primary teachers]. Educational Administration: Theory and Practice, 6(23), 449-466.

Uysal, S., Akbaba Altun, S., \&, Akgün, E. (2010). Okulöncesi öğretmenlerinin çocukların istenmeyen davranışları karşısında uyguladıkları stratejiler [The strategies preschool teachers use when confronted with children's undesired behaviors]. Elementary Education Online, 9(3), 971-979.

Wolfgang, H. C. (1995). Solving discipline and classroom management problems: Methods and models for today's teachers ( $3^{\text {rd }}$ edition). USA: John Willey \& Sons, Inc.

Yagan Güder, S., Alabay, E., \& Güner, E. (2018). Okul öncesi öğretmenlerinin sınıflarında karşılaştıkları davranış problemleri ve kullandıkları stratejiler [Behavioral problems preschool teachers experience in their classrooms and the strategies they employ for these behaviors]. Elementary Education Online, 17(1), 414-430.

Yildirim, A. \& Simsek, H. (2008). Sosyal bilimlerde nitel araştırma yöntemleri [Qualitative research methods in social sciences] (6 ${ }^{\text {th }}$ edition). Ankara: Seckin Publishing.

Yin, R. K. (2009). Case study research: Design and methods ( $4^{\text {th }}$ edition). Thousand Oaks, CA: Sage Publications. 